\title{
Training in Neurology: Rapid implementation of cross-institutional neurology resident education in the time of COVID-19
}

Daniel J. Weber, DO, Dara V.F. Albert, DO, MEd, Bhooma R. Aravamuthan, MD, DPhil,

Miya E. Bernson-Leung, MD, EdM, Danish Bhatti, MD, and Tracey A. Milligan, MD, MS

Neurology ${ }^{\circledR}$ 2020;95:883-886. doi:10.1212/WNL.0000000000010753

\section{Abstract}

In-person resident didactics are traditionally limited to the faculty within a single institution. Teleeducation efforts have been implemented in neurology to various degrees historically, but the coronavirus disease 2019 (COVID-19) pandemic has necessitated a broad and immediate overhaul in neurology didactic training. To respond to the immediate need for resident didactics, we created a rapid onset, volunteer tele-education didactic series publicized on online forums to the American Academy of Neurology A.B. Baker Section via Synapse and the Women Neurologists Group via Facebook. We describe how, with just 1 week of lead time, we created an ongoing neurology lecture series featuring faculty from across the country lecturing on a diverse range of neurology topics. The series is ongoing and draws upwards of 120 residents per lecture. Teleeducation offers unique benefits to enhance the education of all neurology trainees everywhere.

\section{Introduction}

Neurology is traditionally taught in-person through bedside teaching and live face-to-face lectures. However, the use of tele-education in the form of live or recorded online lectures as a means to supplement in-person neurology residency didactic curricula has been discussed in graduate medical education circles for years. There is considerable evidence to support similar outcomes between in-person lectures and online or video lectures in medical education. ${ }^{1-3}$

The traditional in-person educational method limits residents' exposure to the faculty within their institutions. Despite uniformity of core educational requirements for residents, institutional segregation can create different educational experiences, which can be amplified with increasing degrees of medical specialization. Technology-enhanced tele-education allows exposure to a greater variety of educators than would otherwise be available at any single institution.

Due to the coronavirus disease 2019 (COVID-19) pandemic of 2020, typical in-person didactics were abruptly and completely disrupted. All in-person meetings of more than 10 people were deemed unsafe. Our residency didactics simply could not be completed the traditional way. Teleeducation became an ideal way to continue education virtually. Across the nation, several programs took to online meeting platforms to replace their in-person didactics. A great advantage of online video lectures during these uncertain times is that it allows the lecturer and learners to be anywhere while maintaining safe physical distancing. The ability to record online lectures also allows asynchronous review of the information for residents unable to attend the live didactic.

\author{
Correspondence \\ Dr. Weber \\ daniel.weber@health.slu.edu
}

\section{MORE ONLINE}

COVID-19 Resources

For the latest articles, invited commentaries, and blogs from physicians around the world NPub.org/COVID19
In this article, we describe how we took advantage of the opportunity to rise to the challenges of continuing resident education during the pandemic by creating a cross-institutional 
remote lecture series open to learners from around the world. We reflect on our experience thus far and offer lessons learned for others interested in similar educational innovations.

\section{Intervention}

We created an online open-access collaborative teaching platform using the web-based communication platform Zoom (San Jose, CA). This lecture series was designed to be open to all neurology and child neurology residents. With the help of volunteer faculty from the A. B. Baker Section for Neurologic Education of the American Academy of Neurology and the Women Neurologists Group on Facebook (Menlo Park, CA), we took this lecture series from an idea on March 17, 2020, to its first lecture on March 24, 2020.

Faculty were allowed to select the topic with the sole instruction of attempting to avoid redundancy. All available lecture slots were filled by the end of the day of our first lecture. Due to the interest, we extended the series through the end of May. These slots were likewise filled rapidly by board-certified neurologists.

\section{Results}

From our first lecture on March 24 through May 1, we hosted 29 lectures with a total of 3,013 attendee visits from trainees throughout the United States and beyond. In the first week of lectures (Tuesday, March 24-Friday, March 27), we averaged 83 attendees per lecture. In our last 4 lectures prior to the preparation of this publication (Tuesday, April 28-Friday, May 1), that average had climbed than $50 \%$ up to 126 attendees per lecture.

These lectures have been given by 27 different specialists from around the country, representing 24 institutions in 19 states. They were on topics spanning the breadth of neurology (data available at dx.doi.org/10.17632/dg65wscf9s.1). This included topics that may not be easily covered at all institutions, such as pediatric stroke and neuro-oncologic emergencies. Lecturers have incorporated live Q\&A, PollEverywhere questions, and use of synchronous chat features to make the didactics more interactive.

\section{Lessons learned}

Rather than choosing to invite lecturers, we instead chose a more open-source approach and allowed lecturers to join on a

Table Benefits, barriers, and lessons learned from the online learning program

\begin{tabular}{|c|c|c|c|}
\hline & Residents & Faculty & Program directors \\
\hline Benefits & $\begin{array}{l}\text { 1. Exposure to subspecialty topics not available } \\
\text { locally } \\
\text { 2. Exposure to different pedagogical methods } \\
\text { 3. Opportunity to interact with other programs } \\
\text { 4. Additional online resource for learning } \\
\text { 5. Potential for forming community of learning }\end{array}$ & $\begin{array}{l}\text { 1. Opportunity to teach to a wider } \\
\text { audience } \\
\text { 2. Opportunity to interact with other } \\
\text { programs } \\
\text { 3. Career development opportunity with } \\
\text { skill development and building resume } \\
\text { 4. Opportunity to teach for faculty who } \\
\text { may lack local opportunities }\end{array}$ & $\begin{array}{l}\text { 1. Access to subspecialty experts who are } \\
\text { not available within the department } \\
\text { 2. Resident exposure to pedagogical } \\
\text { methods from other programs } \\
\text { 3. External support for didactic curriculum } \\
\text { 4. Potential for cross-institutional } \\
\text { interactions }\end{array}$ \\
\hline Challenges & $\begin{array}{l}\text { 1. Time zone differences } \\
\text { 2. Program commitment to allow time for } \\
\text { attending the lectures } \\
\text { 3. Conflict with local lectures, meetings, and } \\
\text { clinical responsibilities }\end{array}$ & $\begin{array}{l}\text { 1. Lack of skills for virtual teaching } \\
\text { 2. Lack of familiarity with the online } \\
\text { platform } \\
\text { 3. Lack of recognition at local program for } \\
\text { these efforts }\end{array}$ & $\begin{array}{l}\text { 1. Integration to local curriculum and } \\
\text { resident schedules } \\
\text { 2. Understanding significance and } \\
\text { effectiveness of the participation } \\
\text { 3. Lack of control (ability to participate in } \\
\text { the program development and execution) } \\
\text { 4. Inability to implement residents' } \\
\text { feedback on the program }\end{array}$ \\
\hline $\begin{array}{l}\text { Lessons } \\
\text { learned }\end{array}$ & $\begin{array}{l}\text { 1. Need speaker feedback for quality of lectures } \\
\text { 2. Increasing interactions and incorporating } \\
\text { active learning } \\
\text { 3. Adding case-based or discussion sessions, } \\
\text { breakout rooms, round tables } \\
\text { 4. Formal feedback process for the residents to } \\
\text { participate in program development }\end{array}$ & $\begin{array}{l}\text { 1. Providing formal recognition as invited } \\
\text { national speakers } \\
\text { 2. Some vetting process for presenters } \\
\text { 3. Better registration process to be a } \\
\text { speaker } \\
\text { 4. Better ways to recruit speakers } \\
\text { 5. Developing a core cohort of speakers }\end{array}$ & $\begin{array}{l}\text { 1. Involving program directors early on may } \\
\text { enhance engagement } \\
\text { 2. Learning surveys } \\
\text { 3. Better program structure and } \\
\text { organization } \\
\text { 4. More clear effectiveness needs to be } \\
\text { studied } \\
\text { 5. Program director feedback process } \\
\text { needs to be developed }\end{array}$ \\
\hline $\begin{array}{l}\text { Actionable } \\
\text { items }\end{array}$ & $\begin{array}{l}\text { 1. Establish process to collect feedback from } \\
\text { residents } \\
\text { 2. Create a simple postlecture speaker } \\
\text { feedback survey } \\
\text { 3. Incorporate active learning sessions } \\
\text { 4. Survey timing of sessions } \\
\text { 5. Provide resource for residents to reach out to } \\
\text { their program directors and involve them }\end{array}$ & $\begin{array}{l}\text { 1. Introduction video on basics of online } \\
\text { teaching (how-to video) } \\
\text { 2. Develop a speaker signup platform/ } \\
\text { process } \\
\text { 3. Develop a dissemination plan for } \\
\text { recruitment } \\
\text { 4. Offer certificate of recognition } \\
\text { 5. Ask for recording lectures } \\
\text { 6. Identify tools and technologies for } \\
\text { hosting and recording } \\
\text { 7. Provide feedback to the speakers and } \\
\text { have a reinvitation process }\end{array}$ & $\begin{array}{l}\text { 1. Conduct learning and engagement } \\
\text { survey } \\
\text { 2. Establish a process of feedback and } \\
\text { updates } \\
\text { 3. Identify areas of need and focus for most } \\
\text { programs } \\
\text { 4. Understand integration with the local } \\
\text { programs }\end{array}$ \\
\hline
\end{tabular}


volunteer basis. We have demonstrated that this is a feasible method to fill a lecture series and that this method can generate a wide variety of lecture topics that cover content basics (e.g., status epilepticus) but also include topics we may not have otherwise considered (e.g., Parsonage-Turner syndrome) (full topic list available at dx.doi.org/10.17632/dg65wscf9s.1). Volunteer lecturers were eager to teach and to reach a broader audience. Their contribution is recognized on their curriculum vitae as evidence of external speaking. This approach can continue to be used to build future online lecture series, to encourage participation from neurologists who enjoy teaching and to create content diversity.

Resident feedback has continued to be positive. We frequently receive unsolicited emails from the attendees praising the series. We have also learned there seems to be a great interest from trainees in continuing with a series like this in some fashion.

Given the quick start of the project with urgency and lack of precedence, there are clear areas for improvement. To ensure lack of redundancy and ensure coverage of all critical topics, a loose rubric of the number of lectures within given topical areas could have been provided at the outset. Online lectures also allow the opportunity to formally integrate surveys and serial assessments of attendees. An online platform for safe sharing of lecture materials and recordings could have been created at the outset. We also noted varying levels of comfort with presenting virtual lectures over an online platform that would likely change in the future and could represent an area of future faculty development efforts. We have summarized the benefits, drawbacks, and lessons learned from this program in the table.

\section{Future directions}

Rapid implementation of crowd-sourced, cross-institutional farreaching tele-education is possible and highly desired by faculty and residents. Starting the process of tele-education has allowed us to take advantage of the traditional quality improvement plando-study-act cycle. ${ }^{4}$ We are now in the study phase, and have assembled a team to look at how we can continue to improve these lectures that we are currently giving and how we can improve content delivery to residents moving forward. There may also be a role for including medical students and other neurology learners, such as fellows, in this curriculum. Based on what we have seen thus far, there should continue to exist a curriculum given by experts that can be accessed by any trainee regardless of program. This would allow residents access to resources they may otherwise lack. A multi-institutional online didactic series also presents multiple opportunities for qualitative and quantitative education research given the large sample size available. This would allow for rigorous analysis of teaching interventions.

As the next steps, we plan to follow up this initial educational endeavor with a more formal needs assessment to craft an ongoing cross-institutional curriculum that will enhance the knowledge of all future neurologists. This needs assessment should allow us to ensure that the curriculum we present is addressing areas that will be the most helpful and may include subspecialty topics not broadly available, interprofessional speakers, and more global topics. In the ongoing curriculum, speakers will be directly invited with a goal of keeping a broad representation of speakers from the field. We plan to use learner feedback to ensure that excellent speakers are recognized and invited back. We can use this platform to identify qualities associated with speakers who are highly rated by the residents and use that information to inform faculty selection and faculty development tools in the future.

Disruptions on the scale of a global pandemic force adaptation and innovation and can create opportunities for experimentation and change that otherwise might not have been easily achieved. Just as the global pandemic has made tele-medicine a necessity for safe patient care, so too has tele-education become a necessity for safe neurology education. Increased use of tele-education offers unique benefits to enhance the education of all neurology trainees everywhere.

\section{Study funding}

No targeted funding reported.

\section{Disclosure}

D.J. Weber, D.V.F. Albert, and B.R. Aravamuthan report no disclosures. M.E. Bernson-Leung is a former member of the Editorial Board of the Neurology ${ }^{\circledR}$ Resident \& Fellow Section. D. Bhatti reports consulting/speaking for AbbVie, Accadia, Adamas, Allergan Pakistan, Merz Medtronic, and Teva Neurosciences. T.A. Milligan reports no disclosures. Go to Neurology.org/ $\mathrm{N}$ for full disclosures.

Appendix Authors

\begin{tabular}{lll}
\hline Name & Location & Contribution \\
\hline $\begin{array}{l}\text { Daniel J. Weber, } \\
\text { Do }\end{array}$ & St. Louis University, MO & $\begin{array}{l}\text { Designed and } \\
\text { conceptualized } \\
\text { study, analyzed } \\
\text { the data, drafted } \\
\text { the manuscript for } \\
\text { intellectual content }\end{array}$ \\
$\begin{array}{lll}\text { Dara V.F. Albert, } \\
\text { DO, MEd }\end{array}$ & $\begin{array}{l}\text { Nationwide Children's } \\
\text { Hospital, Columbus, OH }\end{array}$ & $\begin{array}{l}\text { Revised the } \\
\text { manuscript for } \\
\text { intellectual content }\end{array}$ \\
\hline $\begin{array}{l}\text { Bhooma R. } \\
\text { Aravamuthan, }\end{array}$ & $\begin{array}{l}\text { Washington University } \\
\text { MD, DPhil }\end{array}$ & $\begin{array}{l}\text { Revised the manuscript } \\
\text { for intellectual content }\end{array}$ \\
\hline $\begin{array}{l}\text { Miya E. Bernson- } \\
\text { Leung, MD, EdM }\end{array}$ & $\begin{array}{l}\text { Boston Children's } \\
\text { Hospital, MA }\end{array}$ & $\begin{array}{l}\text { Revised the manuscript } \\
\text { for intellectual content }\end{array}$ \\
\hline $\begin{array}{l}\text { Danish Bhatti, MD } \\
\text { MD, MS }\end{array}$ & $\begin{array}{l}\text { University of Nebraska } \\
\text { Medical Center, Omaha }\end{array}$ & $\begin{array}{l}\text { Revised the } \\
\text { manuscript for } \\
\text { intellectual content }\end{array}$ \\
\hline $\begin{array}{l}\text { Bracey A. Milligan, } \\
\text { Bospital, Boston, MA }\end{array}$ & $\begin{array}{l}\text { Revised the manuscript } \\
\text { for intellectual content }\end{array}$ \\
\hline
\end{tabular}




\section{References}

1. Brockfeld T, Müller B, de Laffolie J. Video versus live lecture courses: a comparative evaluation of lecture types and results. Med Educ Online 2018;23:1555434.

2. Davis J, Crabb S, Rogers E, Zamora J, Khan K. Computer-based teaching is as good as face to face lecture-based teaching of evidence based medicine: a randomized controlled trial. Med Teach 2008;30:302-307.
3. Markova T, Roth LM, Monsur J. Synchronous distance learning as an effective and feasible method for delivering residency didactics. Fam Med 2005;37: $570-575$.

4. Ting HH, Shojania KG, Montori VM, Bradley EH. Quality improvement: science and action. Circulation 2009;119:1962-1974.

\section{NEW EPISODE}

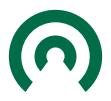

$\underset{\text { PoDCAST }}{\text { Neurology }}$

November 10, 2020

\section{Effect of escitalopram dose and treatment dura- tion on CSF $A \beta$ levels in healthy older adults: A controlled clinical trial (see p. 858)}

In the first segment, Dr. Jeffrey Ratliff talks with Dr. Yvette Sheline about her paper on the effect of escitalopram on CSF A $\beta$. Then, Dr. Stacey Clardy speaks with Dr. Elizabeth Finger about her article on the neural effects of oxytocin on frontotemporal dementia, also from this week's issue.

Disclosures can be found at Neurology.org.

CME Opportunity: Listen to this week's Neurology Podcast and earn 0.5 AMA PRA Category 1 CME Credits' ${ }^{\mathrm{TM}}$ by completing the online Podcast quiz.

\section{Sign Up for the AAN's Axon Registry}

The AAN encourages its US members to show their interest in participating in the Axon Registry。 by signing up today.

Use the Axon Registry to:

- Simplify reporting requirements under MACRA's Quality Payment Program and avoid penalties while reducing your administrative burden

- Meet your MOC Part IV requirements and waive up to eight credits of Part II Self-Assessment

- Choose from 22 AAN neurology-specific quality measures that fit your practice

- Use data to understand your practice and identify where improvements can be made to patient care

- Manage your patients at a population level; look at a specific group of patients based on conditions, risk factors, demographics or outcome

- Demonstrate your value to payers when negotiating reimbursement

- Enjoy multi-year, fee-free access when you sign the agreements and integrate your EHR with the registry

Learn more at AAN.com/view/Axon and send your questions to registry@aan.com. 


\section{Neurology}

\section{Training in Neurology: Rapid implementation of cross-institutional neurology resident education in the time of COVID-19}

Daniel J. Weber, Dara V.F. Albert, Bhooma R. Aravamuthan, et al.

Neurology 2020;95;883-886 Published Online before print September 4, 2020

DOI 10.1212/WNL.0000000000010753

This information is current as of September 4, 2020

\section{Updated Information \&} Services

References

Citations

Subspecialty Collections

Permissions \& Licensing

Reprints including high resolution figures, can be found at: http://n.neurology.org/content/95/19/883.full

This article cites 4 articles, 1 of which you can access for free at: http://n.neurology.org/content/95/19/883.full\#ref-list-1

This article has been cited by 1 HighWire-hosted articles: http://n.neurology.org/content/95/19/883.full\#\#otherarticles

This article, along with others on similar topics, appears in the following collection(s):

\section{All Education}

http://n.neurology.org/cgi/collection/all_education

Computer use in education

http://n.neurology.org/cgi/collection/computer_use_in_education

Methods of education

http://n.neurology.org/cgi/collection/methods_of_education

Other Education

http://n.neurology.org/cgi/collection/other_education

Information about reproducing this article in parts (figures,tables) or in its entirety can be found online at:

http://www.neurology.org/about/about_the_journal\#permissions

Information about ordering reprints can be found online:

http://n.neurology.org/subscribers/advertise

Neurology ${ }^{\circledR}$ is the official journal of the American Academy of Neurology. Published continuously since 1951, it is now a weekly with 48 issues per year. Copyright (C 2020 American Academy of Neurology. All rights reserved. Print ISSN: 0028-3878. Online ISSN: 1526-632X.

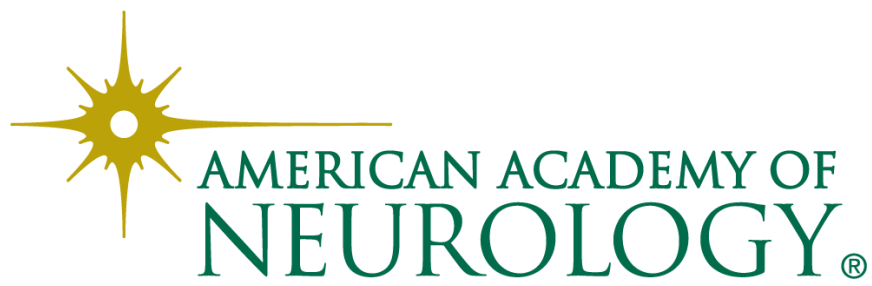

